\title{
Extra Attention Toward Autistic Children: Islamic Psychology Perspective
}

\author{
Yopi Kusmiati ${ }^{1}$, Achmad Syarifudin ${ }^{2}$ \\ ${ }^{1}$ Univesitas Islam Negeri Syarif Hidayatullah Jakarta ${ }^{2}$ Universitas Islam Negeri Raden Fatah Palembang \\ Email: ${ }^{1}$ yopi.kusmiati@uinjkt.ac.id, ${ }^{2}$ achmadsyarifudin73@ radenfatah.ac.id
}

\begin{abstract}
Having an autistic child is a challenge for some parents because an autistic child should be treated specifically, based on condition and ability. The autistic child needs more extra attention than a nonautistic child because the attention from family can accelerate the development and ability of an autistic child, but not all parents can do the treatment because of various reasons. This study aimed to reveal the family's treatment which had an autistic child, especially parent or autistic's sister and brother. The study was done by using qualitative method with a phenomenological approach. The findings showed that there were three treatments of the family to treat an autistic child in daily life, they were extra attention, attention, and inattention. Extra attention was the informant included in the category who gave extra attention to a child. They were strongly caring about their child's ability, food, and education. The attention category was an informant who did not fully give attention to their child, and not all time. The inattention category was an informant who rarely cares for their child, it related to the development of the child, education, and life.
\end{abstract}

Keywords: Autistic Child, Family, Phenomenological Approach

\begin{tabular}{|c|c|c|c|c|}
\hline Submission & Review Process & Revised & Accepted & Published \\
\hline March 3, 2021 & $\begin{array}{c}\text { April 8, 2021 - May } \\
\text { 20, 2021 }\end{array}$ & June 3, 2021 & June 7, 2021 & June 30, 2021 \\
\hline
\end{tabular}

\section{Introduction}

A child is the greatest gift to a family. Whatever, the condition of a child, it must be treated equally, in giving attention to them justly. The parent is the first madrasah for children, so if madrasah is good, it will be good for the children in the family environment. Parent has a responsibility to keep their children from the hell, it means toward their religious life (Q.S. At-tahrim: 6), the parent is obliged to provide a good and appropriate education especially for the parent who has a child with special needs.

The autistic child includes in a category that should get special treatment from the family, and it should be suitable for their needs. There are many ways to treat autistic child, like caring, loving, and some who treat in the same way, like a non-autism child. An autistic child needs more attention than a nonautistic child, because the attention of the family can accelerate the development and ability of autistic child. However, not a few parents have autistic child at first experiences such as anxiety, stress, and even pessimism about their future. Eli Fakhiroh in her thesis (2011) stated when a baby had been waited for a long time, but it was stated by the doctor that the child had an autistic disorder, then it was out of parent's expectations and they felt anxiety. If parent cannot accept, then indifference or neglect of an autistic child can also occur. Permatasari, Rafela Dewi in 2009 found that the lack of facility and more attention to other normal children led parents not to provide special education to autistic child. As a result, the development of selfreliance for autistic child becomes hampered.

The family who has autistic child can treat them based on their development. Therefore, family especially parent needs to know the stage of their child's development. Normally, the stage of a child's development is divided into five periods, namely prenatal, 
newborn baby, infancy, childhood, and adolescence (Gunarsa, 1997).

Based on the stage of development stated by Hurlock, Mussen, and Gunarsa, it can be concluded that every baby will go beyond these stages, as well as autistic child. Autistic child is not a child who has problems in their physical appearance, but in her or his communication and interaction, and based on the development of child physiology and psychology, it can be seen the role of parent and family for the growing period of autistic child, and the treatment of parent in dealing with autistic child. Because autistic child has an emotional condition that is much different from a normal child. The behavior of autistic child is certainly different from normal child, because autism is a disorder in which child has difficulty in interacting with others.

Although not all parents can receive the presence of their child directly, as the results of the study (Kusmiati, 2018) that there were 3 types of parents when knowing their child was autistic baby, namely accepting, rejecting, and accepting with rejection, as parents should still be able to treat their autistic child well, at least by asking him or her to communicate.

Communication is an important part of serving autistic child. Communication is a very complex action, which is not only defined as talking or conveying a message but also about behavior and actions. Every communication has a goal, and to achieve that goal a method is required so that the goal can be achieved optimally.

Good communication between parents, brothers and sisters, or grandparents, even family can be a medicine for autistic child. If the family is unable to communicate well with autistic child and even has a bad attitude, this will negatively affect the child's development. Diah Widiastuti (2014) in her research stated that along with the differences in their behavior, the intervention of both of them is also different. Intervention is given to DNA and tends to be through communication, using an emphasis on such a clear and loud voice such as feeling mad. While BGS is classified as a heavy category, the intervention given to him tends to be through physical action, because of his excessive behavior such as being aggressive and hurting others, treatment through communication will not affect to child.

Therefore, this study aimed to observe family's behavior, especially parents in treating autistic child at home, so that it can be known how the parent treats their children daily. Parent in a family environment is the primary educators for their children. Therefore, a characteristic is as an educator concerning the psychological problems of children, it is very necessary to pay attention. Maghribi (2004) stated several criteria of exemplary educators, namely: a) forgiving and calm, b) kind-hearted and do not be a rude person when interacting to others, c) compassionate heart, d) piety, e) always pray for the child, f) kind-hearted when interacting the child, g) avoiding anger, h) being fair and do not be unfriendly. In the context of parenthood for autistic children, such an attitude needs to get attention. The treatment of the family was analyzed using phenomenological theory, where phenomenology is a theory widely used to see human behavior from a subjective point of view. Phenomenology is a study that studies phenomena, such as appearance, everything that comes up in experience, how something occurs, and the meaning that it has in experience so that the focus of phenomenological attention is more on the conscious experience from a first-person point of view.

Phenomenological tradition emphasizes human perception and interpretation toward their subjective experience. For phenomenologists, individual stories are more important than research hypotheses or communication axioms (Griffin, 
2004). As one of the important and wellestablished approaches in communication research, phenomenological perspective can be used to examine the reality of communication derived from the consciousness of the family of autistic child, since phenomenological studies of knowledge derived from consciousness (Littlejohn, 1996). The reality of communication in this study conducted by the family of autistic child when interacting with their environment, in treating autistic child daily. Parent, as a family should be required to be consistent in education for their autistic child, namely by behaving and treating children by the educational program that has been compiled together between the mentor and parent as a form of generalization of learning at school and home, this is called extra attention.

\section{Research Methods}

In this study, the researchers used qualitative method with phenomenological approaches. To understand the phenomenon of family behavior toward the autistic child at home, the qualitative method was the right method to use, because qualitative research is also an approach or trace to explore and understand a central symptom. With qualitative research, researchers can understand the social problems of humanity.

Creswell (1998) stated that qualitative research is defined as a process of inquiry to understand social or human problems, based on the creation of a complete holistic picture formed in words, reporting the informant's view in detail, and compiled in a natural setting. The subjects in this study were 13 people, consisting of 6 fathers, 6 mothers, and 1 older brother of an autistic child.

Data collection in this study used three techniques, namely observation, in-depth interview, and documentation. Data analysis, the researchers used a data analysis model from Miles and Huberman through 4 stages, namely data reduction, data display, conclusion, and verification.

\section{Results and Discussion}

Based on the results of the study, there were several ways when family treated autistic child in daily life, such as treatment from mother, father, or brother. The treatment was how the family treated for an autistic children.

Some informants in this study almost gave attention to autistic child with the support of other families. All families of autistic children gave special attention to autistic child, it could be seen from the way they provide therapy, found a place to school, and even willing to accompany to go to school, but the attention of each person was different from each other.

Some parents gave extra attention, some were attentive, and some gave inattention, so researchers found three forms of informant treatment that were extra attention, attention, and inattention. The categorization of the researchers was based on the evidence presented by Sch The category of informants giving attention treatment was a SBN, SMJ, SMZ, VM, and SBA. The term of attention utz (Wilson, n.d.). The researchers described each of the categories as follows:

\section{Extra attention}

Extra attention means the informants are categorized as people who give extra attention to autistic child. They fully care about the development of the autistic child, food, and education. Of the thirteen informants, six of them were the informants of $\mathrm{BA}, \mathrm{BN}$ informant, $\mathrm{MR}$, MJ, MZ, and MY.

As a mother, the informant of BA is very good at taking care of her child $\mathrm{AD}$, starting from food, education, and therapy. She is very mobile in arranging all the needs of AD and She had arranged all the AD schedules from morning to afternoon, so it is completely scheduled. Not only 
that, to take care of her child, she willingly stopped working and became a housewife. BA is also always looking for some references from various articles, magazines, and other media to increase her knowledge about autism, as she said: "As soon as I know my child is autistic baby, I immediately look for references in magazines, articles, and go to Harapan Kita Hospital. AD is treated in Harapan Kita 3 times a week. AD and I also got to special school together.

The informant of BA always dropped off and picked up her child and took care from waking up to going to sleep at night. BA was willing to stop working to be able to drop off and picked up her child at school. According to BA, she had to sacrifice her time for the education and development of AD. Not only that, BA and her husband were also willing to move to a place where was closer to the $A D$ school so that AD did not get too tired to go to school.

BA is 42 years old. The informant knew that her son had autism when her son was 1.5 years old. At the first time, BA wasn't sure if her son had autistic disorder, but she kept finding out everything about autism, and compared it to her son's traits at the time. BA knows the autism characteristics from magazines and articles she read. From her readings, she noticed that there were traits inherent in $\mathrm{AD}$, so she assumed that $\mathrm{AD}$ was autistic child. BA also told her husband about her concerns. But at that time BA's husband was not very sure and saw his son's condition was like a normal baby.

This was based on explanation BA as follows: “.......At that time, his father said: mother.. That's normal. Because $i$ have a lot of siblings. He usually takes care of a baby. So that's not to be bothered. Time goes on, I think AD should be checked, if it is not ... Alhamdulillah... finally we take $A D$ to Harapan Kita Hospital, to the child development section". And from the result of the doctor's diagnosis based on signs on the behavior of $A D$, the doctor states that $A D$ was autistic baby, and $A D$ should be treated three times a week".

Ba's Husband agreed to her explanation before and the researchers met at the next meeting. It was very difficult to meet BA's husband, because of his job in the office. Researchers can also meet with the SBA, after making an appointment many times, even on holiday. SBA also accepted researchers well and wanted to answer the questions that researchers asked, although he did not tell as much as BA.

Before marriage, BA worked in a private company. She had a Bachelor of Economics education background, but when AD started attending school, BA stopped working and decided to take care of her son intensively and provides therapy and routinely. Until now BA has never worked again. She spends her time just taking care of her child and husband, which she considers as a gift from Allah SWT.

From researchers' point of view, BA and her husband were parents who deeply cared about the child's development, so willing to sacrifice their work and time for the child. They do not think to seek a lot of money, but they think about how to be able to raise their child by constantly observing their child's development, and taking care of their child.

The parent does not only pay attention in terms of education and therapy, but also the diet and food consumed by autistic child. It also needs to be maintained to support the 
development of autistic child. Food such as fast food needs to be kept away, and a portion of food also needs to be regulated, because the influence of food can worsen the development of autistic child. Based on the researchers' observation, before going to school, BA always prepared juice for $\mathrm{AD}$ and was carried by $\mathrm{AD}$, with variations of juice every day. When the researchers asked BA, she explained when coming home from school AD always wanted to drink juice, and that he always asked when he arrived at school.

The researchers had ever seen the treatment directly when the researchers took $\mathrm{AD}$ to school with $\mathrm{BA}$ informant. When seeing BA's car, AD entered the car and saying hello. After that, her son immediately asked his mother for juice. When there was juice, he immediately enjoyed drinking the juice, while occasionally answering questions given by BA informant and researchers.

The second informant was categorized as the extra-attention is $\mathrm{BN}$ informant. All the activities of her daughter TS were never out of her attention. Since TS has started puberty, she is more attentive than before, because she is afraid of anything happened with her daughter. Since TS was convicted of autism, BN immediately looked for special treatment such as therapy for TS everywhere, even it was in Jogya. This is as the following BN statement: "When TS cannot talk, I take her to the hospital there, therapy for talking, all therapies we had tried because she was 2 years old and she still cannot talk. I take her to Jogja. In Jogja, I know there is a special school for autistic child near my mother's house. So, I stayed in Jogja. In Yogja I probably understand where I must bring my daughter for therapy. At that time, I went to the hospital and the diagnosis was not autistic disorder and it was just ADHD. After moving to Jakarta, we invite speech therapy and behavioral therapy in Bogor. Then, we have treated with a Psychiatrist until my daughter was 5/8 years. When she was 8 years old, she attended a special autistic school in Kebayoran Blok M, Jakarta. My daughter went to school until she was 10. We Stayed in Jogja until she was 4 years, turning to 5 years. While we are in Jakarta, she does in the same time school and therapy. In the morning, she goes to school in block $M$ of a special school for autistic children, immediately at 1 o'clock we have therapy in Bogor".

When TS grew older, until she entered puberty, BN informant gave extra attention to TS, to observe her development. BN feared if she could not observe her daughter, so TS would pass its puberty with excessive emotions, and it often causes tantrum. According to BN, when entering puberty, TS was often grumpy, sat on the table, and slept on the floor. This reasons $\mathrm{BN}$ give extra attention to TS.

Similarly, the food is consumed by TS. BN also never gives foods containing preservatives to TS. The food has been selected by BN. She does not want these foods to become "toxic" in her child's body, because the growth is hampered.

When her daughter was 18 months, BN had known that her daughter was autistic baby. At first, she only wondered for herself about her daughter's condition because she thought her daughter was an abnormality of her inconsistent sleep patterns, and she slept overnight, an unfocused eye gaze and hyperactivity for six months. When examined to the doctor, the doctor only said your daughter was only exposed to ADD and needed therapy, but after she was 2 years old, TS could not talk. BN 
noticed that the development of TS was not good either, and took her to the doctor again for intensive examination, and from the result of the consultation, it was discovered that her daughter was autistic.

Since knowing of TS's autistic condition, BN lived in Palembang with her husband, decided to move to Jogya, to her parents' house to provide therapy to TS. She learned about autistic information from television. From the age of two years until four years, $\mathrm{BN}$ and her daughter lived in Jogya. After TS was four years, they moved to Jakarta, because her husband also moved to Jakarta. And TS therapy was continued in Bogor. TS was also schooled in Blok $M$ when he was five years old. However, TS got older, BN had difficulty finding a TS school, because based on her opinion the autistic school in this area was not very safe for her daughter, finally $\mathrm{BN}$ decided to build her own school with her fellow parents of autistic children.

According to the researchers' view, $\mathrm{BN}$ family is creative. They do not only find a school for a child's education but also build their school for autistic children when their child has difficulty getting a school place. They do not want to stop their child's education because the child has a shortage.

According to $\mathrm{BN}$, the influence of food on autistic child is very noticeable when the child does not limit to consuming food. TS got mad easily, and often tantrum. This was as revealed by BN to researchers: "I do not give TS snacks containing MSG or other preservatives. In the past, she ate snacks and had a tantrum" .

The third informant was MR and worked as a housewife. Since knowing her child was autistic, MR immediately fully gave attention to her child and resigned from the job. MR always pays attention to her child's needs in their economic difficulty. Every day, MR informant serves all the needs of the hospital, such as wearing clothes, preparing food, and accompanying her child to play. MR Informant also always teaches RS to clean the house, help cooking and wash dishes, so that RS can be more independent

MR informant always tries to be able to provide therapy, to get therapy for her child, even though the place is quite far from where they live and go there by public transportation. According to MR, she still has to keep attention to her child's development, even they are poor. As the following MR explanation: "yes, I know I do not have money to treat my child, it is really expensive. I will take my child to a therapy place, and look for the cheap one. if there is money, we go there.

MR informant does not make special food. All the food are in her house, is also consumed by the RS because they eat simple food every day, but MR informant still limits RS to not consume snacks containing preservatives often. MR Informant does not want her child's condition to get worse because of these foods, as the following explanation: "if the food is the same as the one we eat, it is not different. People do not eat various foods. Yes, it's simple and delicious food. if my child wants to eat snacks, I will limit, because the doctor said it's a danger to $R S$. It's getting worse ".

The same way was done by MZ informant, as the fourth informant who was also highly skilled in providing therapy for her child AZ. Every day, MZ informant invites $A Z$ to do Brain Gym and takes a picture through digital photos. All the therapies she tried and applied directly to $A Z$, because she wanted AZ to have progress quickly. As the following 
explanation: "when I know AZ is autistic, I follow all suggestions from a doctor, join the therapy. When my child was 3 years, $I$ entered my child to Talitakum, with $A B A$ approach and ABA therapy. I also do Balur therapy, so it's like detoxifying mercury. Luckily, there's a lot of change. I also participate in seminar and workshop for about 5 months until $i$ join all the practitioners".

Preferential treatment is also obtained by other autistic child and they are $\mathrm{MZ}$ family. AZ is truly over-loved by the entire $M Z$ family more than other families. This was also seen when grandfather picked up AZ to school when MZ could not deliver AZ to school, even though grandfather lived in a place far enough from MZ's house, even the grandparents were willing to stay at MZ's house, to take care of $\mathrm{AZ}$ or $\mathrm{MZ}$ was sick or had an important job that could not take AZ.

Besides that, $\mathrm{MZ}$ also really pays attention to the food which will be consumed by AZ, such as diet and food. $\mathrm{MZ}$ does not want to give food carelessly to her child. The food is cooked by MZ at home, because she does not want if the food contains petsin, MSG, or other preservatives. AZ always brings a lunchbox from home when he goes to school, swims, or goes somewhere. This is corroborated by the following $\mathrm{MZ}$ explanation: "... I always pay attention to everything, because my child cannot eat carelessly, and it contains MSG and preservatives. So I prepare all the food. That's why $i$ do not have a maid. If my child eats it carelessly, $i$ cannot imagine the condition".

The fifth informant was MJ and included in the extra-attention category. She always gave attention to her child JG, such as development, ability, food, and education. She always took JG to school, even waiting for her child until finishing school. She also learned some methods of autism and shared them with other parents.

MJ observes JG's progress at all times, in terms of ability to speak, write, paint, or other abilities. Every development or change experienced by JG is never missed by $\mathrm{MJ}$, even she immediately types it on her laptop she always carries. MJ also never tried to invite JG to tell stories, although there is no response from $\mathrm{JG}$, to stimulate the development of communication. MJ is also very active in providing treatment to JG and she does it as well as possible. As she expressed the following: "for treatment, I have to be active in doing it, to improve JG, and that I do hard". Similarly, the food is really to be considered. The food is MJ's control. She does not want JG to eat food containing preservatives, although sometimes JG is free to choose food.

Next informant was also a housewife. MY had been very concerned about YS since YS was convicted of autism. She is also very diligent in taking YS to the pediatrician, a therapy place, and consulting with a psychologist. Here was what she said: " when there was speech delay, I took my child to a pediatrician. Then I took my child to Jogya, and consulted with a doctor for a checking up. I took him to the psychologist as well. some feedbacks from psychologists that I tried at home. So I got homework from the psychologist, what $i$ should do to stimulate the growth of YS communication".

MY always pays attention to YS's behavior when her child is playing, chatting with friends at school, and watching television. The food is controlled by MY. MY is very concerned about the food consumed by YS as well as 
diet, although MY does not strictly prohibit YS from eating other food. Here was an explanation with MY informant:

"If the diet is regulated, and $i$ select healthy food. YS my child cannot eat carelessly. I am so sad too if my child wants to eat the food seen on television. I want my child to be like any other child. My child likes to try new food. Then, my child drinks special milk for allergies. YS cannot drink cow's milk".

The treatment of these informants is a form of great attention to their children, for the growth of their children. Furthermore, the researchers described informants who were categorized as attention.

\section{Attention}

The category of informants giving attention treatment was a SBN, SMJ, SMZ, VM, and SBA. The term of attention means the informants did not fully pay attention to autistic children, and not all the time. The reasons were such as working in the office every day, to fulfill their daily needs, especially for the needs of their autistic children.

As office workers, SBN, SMJ, SMZ and SBA informants always go to the office every morning and go home at night, and sometimes it is tonight, so on a weekday, they cannot give extra attention to their children specifically. But they still monitor their son's progress through their wives. At night, the informants also still take the time to communicate with their autistic children, at least to ask them to tell about their activities at school and at home. As revealed by the following SBA informant: "If I go back home, I usually always ask $A D$, activity $A D$ in school, such as studying and playing, and meals. AD sometimes asks dad to accompany him watching television, then plays games until the child sleeps. Alhamdulillah, I still have time to accompany and communicate with $A D$. If $i$ do not have time in the evening, we talk at breakfast time. I always have breakfast together, so I can talk with AD. After having breakfast time, I go to the office directly.

Furthermore, SBN and SMJ informants always spend their time accompanying their children such as traveling, watching at the cinema. SBN always takes TS going to the mall, goes to the bookstore, or watches movies that TS likes. SBN sometimes hangs out with TS without coercion. TS is very happy if his father is on holiday and even always asks when his father is off again, and always waits SBN from the office. As revealed by the following SBN informant: "TS likes watching, and on Sunday night when I'm at home, I take TS going outside. If there is a good movie, I take my child to the cinema. Or we accompany my wife to go shopping at the mall. TS is always happy".

For TS education, SBN informant supports his wife BN to build a special school for autistic children, because they are also very worried about TS education. TS and his wife do not want TS to enter public school when TS gets older. Not only encouraging but also making monetary contribution TS got.

The next informant was SMJ. The informant often took JG to go to recreation places, even SMJ often went abroad. JG is happy about traveling, so SMJ, JG's pleasure is the important thing. SMJ realizes he seldom spends his time with JG, SMJ works at the office all time. When SMJ has free time, he spends time with his children, especially JG. SMJ pays extra attention to JG when they are outside. Whether going to the mall, or beach, the informant always takes care and 
holds JG's hand. When the researchers asked some informants, they revealed that:

"his father really loves JG, hangs out together. Where we are going, he is with us. JG is a friendly child. JG likes going outside with his father. Well, if his father comes home, my child can jump around. He is so happy. He immediately grabs the shoes. He is ready to go with his father. My husband often goes home at night. He cannot play and feel tired, even though he wants to play with JG. So, if my husband has time, we go somewhere. "

Education and therapy are important things for the development of JG. She deeply cares about them. SMJ always monitors JG's progress, discusses his school with MJ, and i and my husband bring JG to therapists abroad. SMJ never complained about expensive costs for JG, even though he worked alone to support his family and fulfill all of JG's needs. In my husband's opinion, it's all arranged by God, and his sustenance for JG is always there.

The same condition was felt by SMZ and worked to fulfill the needs of families and his autistic child. SMZ is concerned about AZ's educational needs, and AZ's vacation needs, so SMZ always spends his time taking $\mathrm{AZ}$ sightseeing. When SMZ was at home, he spent his time chatting with AZ, listened to AZ's story, and accompanied $\mathrm{AZ}$ to watch $\mathrm{TV}$ or painted in his room. The researchers saw from some photos on AZ's Facebook and SMZ's media social such as going several places and swimming. SMZ informant also expressed the following: "if $i$ have holiday time, we usually swim together. In the past, iforced him to swim because i did not want him to be a spoil child. When he was four years old, he has been able to swim. The ability to balance will be good.
When i am at home, AZ often plays and watches with me".

SMZ informant also always accompanied AZ when AZ was participating in autism activity at school and other places. When AZ participated in a painting competition for autistic children to commemorate autistic children's day all worlds and participated in art performance at his school. By observing from display picture photos, $\mathrm{MZ}$ always posted photos of $\mathrm{AZ}$ activities.

The same condition was felt by the VM informant. He is the older brother of autistic child. VM is also very attentive to his sister, and understands YS's desires at home, although their age is not far from each other. YS is also his responsibility as an older brother. He always reminded YS to take a shower, eat food, and pray. VM also liked to take YS to the park near their house with our maid. Not only at home, at school, but VM informant was also really concerned to his sister, worries about something if they are in one school. VM informant explained: "if there is my mother and older sister at home, YS is always with them. Then, I also like reminding YS to take a bath, eat, pray. Luckily, YS is really on time when praying and he prays five times a day, how about me? I sometimes pray and sometimes $i$ do not pray. I also like playing badminton with YS and my older sister, play ball on the field with shadow teacher too".

The attention of VM informant was also seen from his affection for YS, such as what kind of food could be consumed by YS. Then, I often accompanied YS to watch television and play games.

These forms of attention are one of their concerns when some informants are at family, without giving up their responsibility and concern for autistic 
children. The next category was inattention.

\section{Inattention}

The category of inattention included some informants who were less concerned with their children, in terms of their ability, education, and environment. These Informants seldom communicated with their autistic children, unless they were forced or there was important to be conveyed. SMR and SMY informants were inattention category.

The informant did not feel guilty or sad about the condition of his son (RS). Since RS was an autistic baby, SMR never cared about his child and did not want to know anything about RS. His time was spent outside as if he wanted to avoid meeting with RS. He often came home tonight when RS had slept. The next day SMR left home early morning as fast as possible when his wife was busy taking care RS. MR informant revealed: "He always comes home at eleven o'clock or twelve o'clock p.m. he does not care about his child, RS".

When RS was still a baby, SMR also never accompanied his wife went to hospital to have therapy or found some information about therapy places for RS. Everything was done by MR and went to therapy hospitals alone. MR went to the hospital by public transportation. SMR's attention and concern were never felt by RS until our child grew up.

SMY did not care about his autistic child. Since YS was an autistic child, SMY informant rarely interacted with YS, or just had fun. His wife always handled everything. According to the informant, SMY started talking with YS when he was
4 years old, although it was a simple conversation. The informant explained: "my husband starts talking YS when he was four years. It's a simple conversation".

At home, SMY only had a simple conversation with YS, even it seldom happened. There was almost no communication between SMY and YS. When MY is not at home, YS is more served by a maid and the maid is very close and can understand YS more than SMY. SMY assumed that there was nothing happen between SMY and YS, and did not need special attention. SMY also never accompanied YS to therapy or school.

When YS got older and entered puberty, attention and treatment still have not changed much, and never started a conversation with YS, except accompanying YS go to market or to the barbershop. This is based on the explanation from MY and her maid: "my husband rarely has a conversation with YS, unless I ask him directly, especially playing with YS. He said I am dizzy. Now, my husband sometimes asks YS to go to market and barbershop together because I ask for it ${ }^{1}$ ". Meanwhile, the maid explained: "YS' father seldom talks to YS and in the room meanwhile YS often watches upstairs. Bapak also seldom accompanies YS to play. If Ibu is at home, YS plays with me, like disturbing me. But he understands if $i$ tell him. He is a good boy".

A lot of efforts were done by MY to have good relationship between YS and SMY. From the researchers' point of view, it was a good effort, for example jogging with YS on sunday morning, going to the

\footnotetext{
${ }^{1}$ Interview with MY on december, 19, 2011
} 
mosque, or swimming. However, MY said that there is no progress because SMY does not care about YS. In a short time, SMY sometimes accompanied YS to walk every morning, but it did not last long.

Based on the researchers' observation, when seeing SMY and YS in the morning, they walked alone. YS was behind meanwhile SMY was in front of him. When they were at home, YS came down from upstairs, there was no greeting from SMY to YS. He went straight into the room. YS does not seem to care much about his father, and just greets his mother

The feeling of inattention is felt by MY informant, whether it is at home or outside. When attending our family events, like weddings or family gatherings, SMY informant never wanted to be close to his son, he stayed away from YS. Likewise, when hanging out together, SMY informant also did not want to be bothered with YS. He only noticed his second child, without caring where and what YS was at the time, so their holiday often failed because of SMY's attitude to YS.

The inattention by the informants, SMR and SMY, was an attitude of their rejection of their children who had autism, so they thought it was not necessary to give special attention to their children, and it was their rebellious attitude towards what they received. To see the categories of the informants, the researchers had listed in the table subtitles

Based on the research results, it can be seen that the treatment shown by families to autistic children was a form of serious attention from family to them, for instance, the intense attention that carried out by the informants, BN, BA, MR, MJ, $\mathrm{MZ}$, and MY. As a mother, they grasped the idea that family has an important role for autistic children that cannot be replaced by other people who have no blood relation. In congruence with what Trenholm said that family has internal and external functions. "Internal functions keep the system running and serve the individuals who make up the family unit, and external functions or service are provided to the larger society". (Trenholm, 1992). In this case, the internal functions are mostly related to psychosocial functions such as socialization, intellectual development, recreation, and emotional support, while the external functions are related to the transmission and accommodation functions, whose attention focuses a lot on how to protect the family from values, social norms that against the values and family norms

In addition, the informants were also very aware of their role as mothers who needed to communicate continually with their children, because their personalities were unique to their children. They were also very aware of the importance of communication in the family for the development of their children, both communication through words, gestures, actions, expressions of feelings, and understanding.

It also happened to the other informants, SBN, SMJ, SMZ, and SMY, who also paid attention to their autistic children, because they spent much time to their work, they could not pay attention and accompanied their children all the time as their wives did, mostly they have 24 hours for their children. The four informants were always open to listen to all information regarding their children, whether it was about their children's development, education, and the problems that their wives faced while dealing with their children at home, as well as their children's development reports at school. 
From this, it can be concluded that communication in their family was fine, whether it was related to pleasant or unpleasant things.

Meanwhile, inattention
treatment from the informants, SMY and SMR, was a form of discomfort in the family due to lack of communication and made their children unable to communicate with their parents. Although this form of attention was caused by the lack of acceptance from the informants, SMY and SMR, it caused a rigid communication between SMY and SMR and their children, so that it was difficult for them to understand their children, and made them tend to not care about the situation of their children, as if they pulling away from the lives of their children who have autism. This was the interpretation of the reality of the informant's experience that became the basis for the informant's behavior in dealing with children with autism. By Schuts' that reality is based on the understanding or meaning of the action. Therefore, according to Schutz, a person's actions are defined as behavior that has a subjective meaning

Unfortunately, every parent should accept their children regardless of their condition, by caring for them. As Rohner argued, parents accept their child's condition will be shown by hugging, kissing, giving attention, caring, supporting, and provide comfort to the child, so that the child will feel happy and safe when near his parents (Rohner, 2004). Therefore, the family should provide a comfortable feeling to their children, such as a comfortable environment, varied activities, and continue to communicate with autistic children and involve family members in caring for autistic children. Families must also create a home atmosphere that is beneficial for the health and development of family members by facilitating the needs of each family member and still support each other in a variety of situations. Providing comfort to autistic children is done by caring and providing instructions for the ability to fulfill the wishes of the child.

Based on the information, it can be stated the family was indeed the best place for children to grow up like any child's condition, normal or abnormal. Some informants always want to give the best thing in various ways, even the special treatment is not cheap. Some wishes of the family, especially the mother who is closer psychically, always teach her child to be independent when having hard problems someday and have the attitude of independence, so the child does not need helping from the others. This can be seen in the physical development of autistic children.

While the attitude of rejection family can be a bad impact on autistic children because according to Marijani, it made autistic children feel incomprehensible and is not accepted their thought and themselves. Then, there is a rejection from the child which is then manifested in the form of unwanted behavior. And if this has already happened, it would further worsen the condition of harmony in the family, family members feel confused about the existing situation (Marijani, 2003).

Good treatment of autistic children had specifications and would have a psychologically positive impact on them. The category of extra attention of autistic children can develop a sense of comfort in themselves, they would interact and feel the same with normal children. Islam teaches people to be grateful and patient. Therefore, having autistic children is not a 
disgrace, if faced patiently then the reward is better than ignoring it.Here is a table describing how families treat autistic children:

Table 1.

Family treatment toward autistic children

\begin{tabular}{|c|c|c|c|c|}
\hline No & $\begin{array}{l}\text { Informan } \\
\text { Name }\end{array}$ & $\begin{array}{c}\text { Extra } \\
\text { Attention }\end{array}$ & Attention & Inattention \\
\hline 1 & $\mathrm{BN}$ & $\sqrt{ }$ & & \\
\hline 2. & SBN & & $\sqrt{ }$ & \\
\hline 3. & MR & $\sqrt{ }$ & & \\
\hline 4. & SMR & & & $\sqrt{ }$ \\
\hline 5. & MJ & $\sqrt{ }$ & & \\
\hline 6. & SMJ & & $\sqrt{ }$ & \\
\hline 7. & $\mathrm{MZ}$ & $\sqrt{ }$ & & \\
\hline 8. & SMZ & & $\sqrt{ }$ & \\
\hline 9. & MY & $\sqrt{ }$ & & \\
\hline 10. & SMY & & & $\sqrt{ }$ \\
\hline 11. & $\mathrm{VM}$ & & $\sqrt{ }$ & \\
\hline 12. & $\mathrm{BA}$ & $\sqrt{ }$ & & \\
\hline 13. & SBA & & $\sqrt{ }$ & \\
\hline
\end{tabular}

Source: the data was gotten from research finding

Based on the table, it can be concluded that the total of informants who treated autistic children with extra attention was six people, informants who treated them with attention was five people, and informants who treated them with inattention was two people, where extra attention is gotten from their mother.

\section{Conclusion}

This study aimed to reflect parent's attention which had a positive impact psychologically on their child. In addition, family care became an important treatment for autistic children to be able to build communication between themselves, their families, and their environment. The greater the family's attention to children with autism will be better the growth of children so that they can actualize themselves and participate in other positive activities.
In addition, parents as the closest family need to be fully aware that autistic children are a valuable gift from God and must be cared for. Therefore, extra attention is given to them to be part of society decently and by their physical development. There were three ways how the parent treated autistic children's daily life, namely extra attention, attention, and inattention. Extra attention was the informant always gave extra attention to detail. They care deeply about the development of autistic children, food, and their education. Islam cares deeply about people, including autistic children.

It is inappropriate to discriminate against children because of innate factors such as incapable to do something. Family should keep their children as good as possible to be good children and this is an absolute sacred mission for parents and families. Three ways were used in treating autistic children, and extra attention and attention were the recommendations in treating autistic children. Uniquely, the parents thought that it was fine and commonplace. Even their behaviors towards their autistic children were deemed sufficient.

Parents should increase interaction with other parents who had autistic children, even need to increase knowledge in dealing with autistic children so that the development of self-reliance of their autistic children could be better over time. Therapy for autistic children also needed to be understood so that what was encountered in their school (SLB), can be developed again at home.

\section{References}

Creswell, J. W. (1998). Qualitative Inquiry and Research Design: Choosing Among Five Traditions. California: Sage publications, Inc.

Griffin, E. A. (2004). A First Look at Communication Theory. New York: McGraw Hill. 
Gunarsa. (1997). Dasar dan Teori Perkembangan Anak. Jakarta: PT BPK Gunung Mulia.

Kusmiati, Y. (2018). Sikap Keluarga Terhadap Kehadiran Autisme: Salah Satu Bentuk KOmunikasi Keluarga. Wardah, 19(02), 158. Retrieved from http://jurnal.radenfatah.ac.id/index.php/ warda/article/view/2817

Littlejohn. (1996). Theories of Human Communication. New Mexico: Wodsworth Publishing Company.

Marijani, L. (2003). Peran Orang Tua Pada Anak Autis. Makalah Konferensi Nasional Autisme-1.

Maghribi, A. (2004). Begini seharusnya mendidikanak: Panduan mendidik anak sejak masa kandungan hingga dewasa. Jakarta : Darul Haq

Rohner, R. (2004). Parental acceptancerejection.

Trenholm, S. (1992). Human Communication Theory. New Jersey: Prentice Hall.

Wilson, T. D. (n.d.). Alfred Schutz, phenomenology and research methodology for information behaviour research.

Mirza, Rina, (2016), Menerapkan Pola Asuh Konsisten pada Anak Autis, jurnal Tarbiyah, Vol.23 No.2

Fakhiroh, Ely (2011) Studi Deskriptif mengenai penerimaan dan perlakuan orang tua serta keluarga pada anak Autis. thesis, IAIN Sunan Ampel Surabaya.

Arohim, Yosep Timan, (2019) Model Terapi Applied Behaviour Analysis untuk anak Autis di Klinik Kailila Kota Pekanbaru, Skripsi thesis, Universitas Islam Negeri Sultan Syarif Kasim Riau.

Permatasari, Rafela Dewi, (2009) Ketidakpedulian Keluarga Yang Memiliki Anak Autis Terhadap Pendidikan Remaja Autis (Studi Kasus Pada Keluarga Dengan Ayah Yang
Berprofesi Guru Di Desa Sumbergirang Kecamatan Lasem Kabupaten Rembang), Skripsi, Universitas Negeri Semarang 